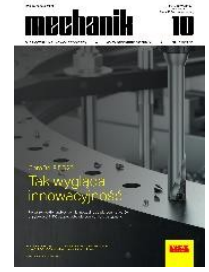

\title{
Tests for lapping of flat surfaces of ceramic elements with forced dosing of abrasive slurry
}

\author{
ADAM BARYLSKI \\ MACIEJ GNIOT *
}

Prof. dr hab. inż. Adam Barylski, abarylsk@pg.edu.pl, https://orcid.org/0000-0003-1672-8445 - Wydział Mechaniczny Politechniki Gdańskiej, Gdańsk, Polska

Mgr inż. Maciej Gniot, maciej.gniot@utp.edu.pl, https://orcid.org/0000-0002-2707-0696 - Wydział Inżynierii Mechanicznej Uniwersytetu Technologiczno-Przyrodniczego, Bydgoszcz, Polska

The issues related to the forced dosing system of the abrasive slurry in single-disk lapping are presented. This system allows dosing of a suspension with different fluid viscosities. The innovative system developed was adapted to work on the Abralap 380. The advantages of this type of abrasive sling dosing system and the procedure for planning testing of lapping of flat elements from technical ceramics, on the example of $\mathrm{Al}_{2} \mathrm{O}_{3}$ treatment, are described. Selected results of defect investigations are presented, which were subjected to detailed statistical analysis.

KEYWORDS: lapping the flat surfaces, forced dosage abrasive slurry

\section{Introduction}

The lapping process for flat surfaces is mainly carried out on single-disc lapping machines $[4,11,12]$. The effectiveness of this finishing treatment depends on many factors. They are related to the machined material, type and properties of the lapping disk, kinematic conditions of the machine tool, exerted unit pressure on the lapped elements as well as the type and characteristics of the abrasive micro-grains used in the suspension. The dosage method of the abrasive slurry itself has a great influence $[1,2,5]$.

In the case of free (continuous) feeding of the slurry, some of the abrasive micro-grains are removed very quickly from the active surface of the lapping machine (through the separating rings moving on it and the machined elements) and does not participate in cutting [3]. For this reason, at the Gdansk University of Technology, in cooperation with the University of Technology and Life Sciences in Bydgoszcz, a forced (periodic) method of dosing the abrasive slurry is developed $[6,8,9]$; selected results of these tests are presented in the paper. An example of one-sided lapping of ceramic elements was used.

\section{Experimental research model}

As input (examined) factors adopted in the study, there were following (fig. 1):

- $K$ - content of abrasive grains in the carrier substance [\%],

- Vs - amount of dosed abrasive slurry within $20 \mathrm{~min}$ [ml/20 min],

- Le - viscosity of the mixture of liquid components in the slurry [mPa.s].

Fixed test conditions were:

- $C D 1$ - rotational speed of the lapping disk [rpm],

- CD2 - machined material,

- $C D 3$ - lapping kinematics, lapping material as well as the size and method of applying pressure to the elements (machining station),

- $C D 4$ - device construction for forced dosing of abrasive slurry.

Interferences occurring in the process mainly concern:

-UD1 - voltage drop in the electrical network,

-UD2 - height spread of samples machined simultaneously.

The result (output) factor was $\mathrm{Ubl}$ - linear loss of samples [ $\mu \mathrm{m}]$ 


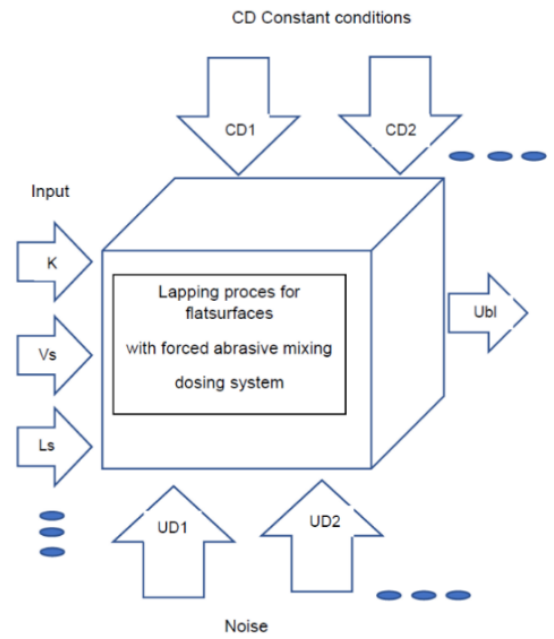

Fig. 1. Diagram of flat surface lapping tests

The study used micro-grain silicon carbide 98C F400/17, dosed to a cast iron lapping disk. The average lapping speed was: $0.58 \mathrm{~m} / \mathrm{s}$, and value of the unit pressure: $0.045 \mathrm{MPa}$. A mixture of machine oil and kerosene was used as the liquid substance in the dosed abrasive slurry.

TABLE I. Values of tested factors

Code values of tested factors

\begin{tabular}{|c|c|c|c|}
\hline \multirow{2}{*}{ Sample number } & \\
\hline & $\begin{array}{l}\text { Content of abra- } \\
\text { sive grains } K[\%]\end{array}$ & $\begin{array}{l}\text { Amount of abrasive } \\
V_{s}[\mathrm{ml} / 20 \mathrm{~min}]\end{array}$ & $\begin{array}{l}\text { Viscosity of a liquid substance in suspension } \\
\qquad L_{e}[\mathrm{mPa} \cdot \mathrm{s}]\end{array}$ \\
\hline 1 & -1 & -1 & -1 \\
\hline 2 & 1 & -1 & -1 \\
\hline 3 & -1 & 1 & -1 \\
\hline 4 & 1 & 1 & -1 \\
\hline 5 & -1 & -1 & 1 \\
\hline 6 & 1 & -1 & 1 \\
\hline 7 & -1 & 1 & 1 \\
\hline 8 & 1 & 1 & 1 \\
\hline 9 & -1.682 & 0 & 0 \\
\hline 10 & 1.682 & 0 & 0 \\
\hline 11 & 0 & -1.682 & 0 \\
\hline 12 & 0 & 1.682 & 0 \\
\hline 13 & 0 & 0 & -1.682 \\
\hline 14 & 0 & 0 & 1.682 \\
\hline 15 & 0 & 0 & 0 \\
\hline 16 & 0 & 0 & 0 \\
\hline 17 & 0 & 0 & 0 \\
\hline 18 & 0 & 0 & 0 \\
\hline 19 & 0 & 0 & 0 \\
\hline 20 & 0 & 0 & 0 \\
\hline \multicolumn{4}{|c|}{ Values of tested factors } \\
\hline & \multicolumn{3}{|c|}{ Before coding } \\
\hline Code values & $\begin{array}{l}\text { Content of abra- } \\
\text { sive grains } K[\%]\end{array}$ & $\begin{array}{l}\text { Amount of abrasive } \\
V_{\mathrm{s}}[\mathrm{ml} / 20 \mathrm{~min}]\end{array}$ & $\begin{array}{l}\text { Viscosity of a liquid substance in suspension } \\
\qquad L_{e}[\mathrm{mPa} \cdot \mathrm{s}]\end{array}$ \\
\hline$-1,682$ & 5 & 10 & 10.3 \\
\hline-1 & 9 & 26 & 16.5 \\
\hline 0 & 15 & 50 & 23 \\
\hline 1 & 21 & 74 & 29.5 \\
\hline 1,682 & 25 & 90 & 34 \\
\hline
\end{tabular}




\section{Program and selected research results}

General view of the dosing system used for the abrasive slurry is given in fig. 2.

A static, determined, selective, multifactorial, quasi-rotational, second order [10] study plan developed by Box and Hunter [7] with a spherical distribution of information was applied in the experiments. It ensures constant estimation of the regression function in a certain environment of the central point of the PS/DS-P: $\lambda$ plan [13].

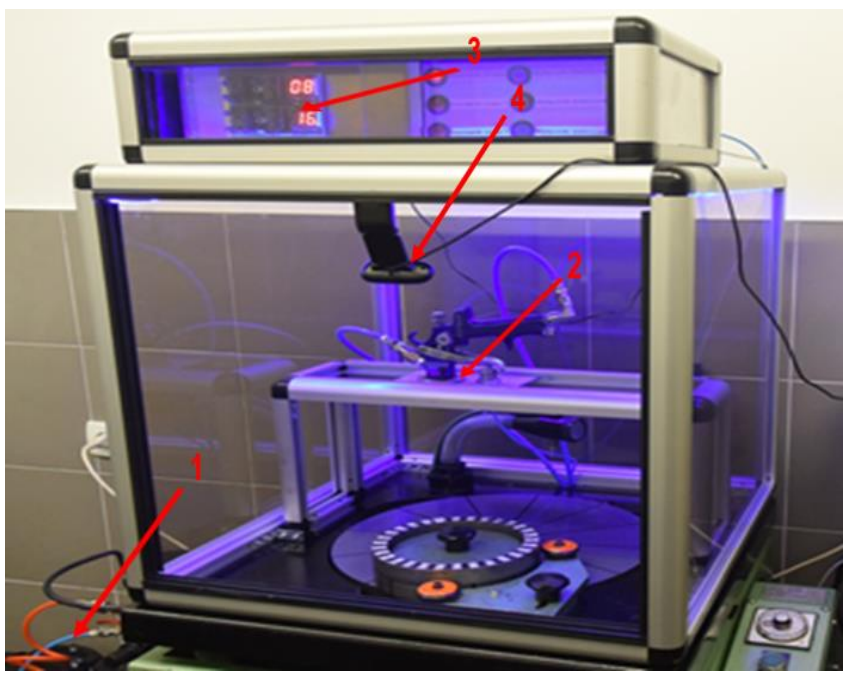

Fig. 2. Forced abrasive slurry dosing system: 1 - continuous slurry mixing system, 2 - abrasive slurry dosing system on the lapping disc, 3 - control system, 4 - process recording camera

The plan is characterized by relatively high informativeness and efficiency, which is important from the point of view of the cost-effectiveness of the research. It requires $n=20$ tests to be carried out with the given values of the tested factors listed in tab. I.

Mathematical function determined on the basis of experimental data has the form:

$$
U b_{1}=b_{1} X_{1}+b_{2} K+b_{3} V_{\mathrm{s}}+b_{4} L_{\mathrm{e}}+b_{5} K^{2}+b_{6} V_{\mathrm{s}}^{2}+b_{7} L_{\mathrm{e}}^{2}+b_{8}\left(K \cdot V_{\mathrm{s}}\right)+b_{9}\left(K \cdot L_{\mathrm{e}}\right)+b_{10}\left(V_{\mathrm{s}} \cdot L_{\mathrm{e}}\right)
$$

where:

$U b l$ - linear loss of samples [ $\mu \mathrm{m}]$,

$K$ - content of abrasive grains in the carrier [\%],

$V s$ - dose of abrasive slurry [ml/20 min],

$L e$ - viscosity of the liquid mixture in the abrasive slurry [mPa's],

$b 1, b 2, b 3, b 4, b 5, b 6, b 7, b 8, b 9, b 10$ - equation coefficients,

$b 1 x 1$ - free component, where: $x 1=1$.

From the analysis of the impact of three examined factors on the linear defect of the lapped ceramic samples, values of the coefficients of the quadratic equation were obtained, which are contained in tab. II.

\section{TABLE II. Coefficients of the quadratic equation}

\begin{tabular}{|c|c|}
\hline $\mathrm{b}_{1}$ & -571.550 \\
\hline $\mathrm{b}_{2}$ & 38.6214 \\
\hline $\mathrm{b}_{3}$ & 1.2930 \\
\hline $\mathrm{b}_{4}$ & 30.8078 \\
\hline $\mathrm{b}_{5}$ & -0.9653 \\
\hline $\mathrm{b}_{6}$ & -0.0163 \\
\hline $\mathrm{b}_{7}$ & -0.6466 \\
\hline $\mathrm{b}_{8}$ & 0.0226 \\
\hline $\mathrm{b}_{9}$ & -0.3077 \\
\hline $\mathrm{b}_{10}$ & 0.0401 \\
\hline
\end{tabular}

Fig. 3 shows the impact of the percentage of grains in the abrasive and the applied dose of slurry on the lapper during 20 min on the linear loss of samples. 


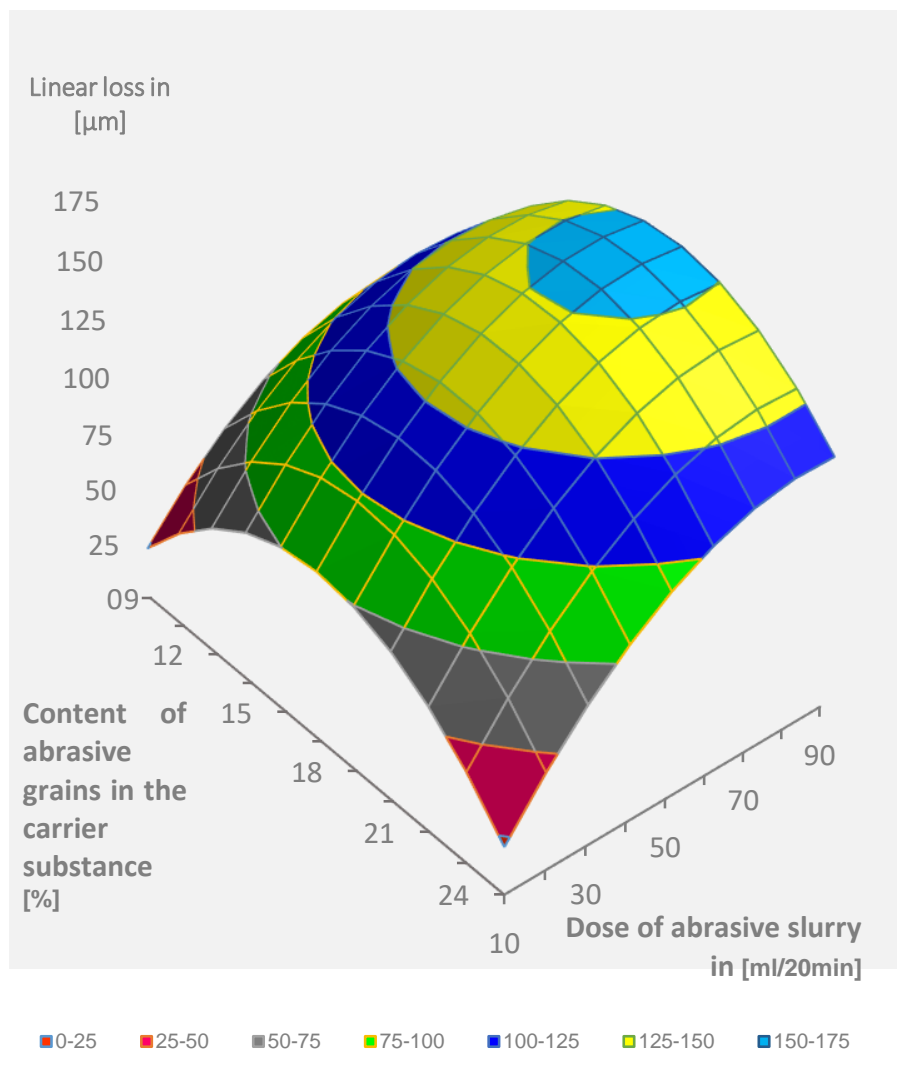

Fig. 3. Linear loss of $\mathrm{Al}_{2} \mathrm{O}_{3}$ technical ceramics, lapped on a Abralap 380 single-disc lapping machine, with a forced abrasive slurry dosing system

As a result of analyses, it was found that the viscosity of the liquid substance in the abrasive slurry (in the test range) has no significant impact on the loss of processed elements. From a practical point of view, the most important impact is the dose and percentage of abrasive grains.

The experiment adopted a range of this dose from $10 \mathrm{ml} / 20 \mathrm{~min}$ to $90 \mathrm{ml} / 20 \mathrm{~min}$. The best results in terms of process efficiency were obtained at the dose of $90 \mathrm{ml} / 20 \mathrm{~min}$. The influence of abrasive grains content in the carrier substance was also analyzed. For the purposes of the experiment, the content range of silicon carbide grains in the carrier substance - prepared on the basis of machine oil and cosmetic kerosene - was determined from $5 \%$ to $25 \%$. It was found that the best effects of linear loss of ceramic samples can be obtained if the content of abrasive grains in the carrier substance is about $15 \%$.

\section{Summary}

Based on the research carried out upon the impact of forced dosage and application of abrasive slurry on the working surface of a cast iron lapping machine on the effectiveness of the lapping process of flat elements made of $\mathrm{Al}_{2} \mathrm{O}_{3}$ ceramics, it can be concluded that:

- forced dosing system contributes significantly to savings associated with the consumption of abrasive slurry, - the applied dosage method of the slurry generates smaller amount of harmful substances that should be subjected to costly disposal,

- significant impact on the efficiency of the lapping process is exerted by appropriate selection of the percentage of abrasive grains; in the analyzed case, the best results were obtained with a $15 \%$ share of abrasive grains in the carrier substance,

- excessive content of abrasive grains does not increase the efficiency of the lapping process,

- an important factor influencing the efficiency of the lapping process is the amount of abrasive substance per revolution of the lapping disc,

- based on the conducted experiment, it was found that the largest material loss was obtained using a total dose of $90 \mathrm{ml} / 20 \mathrm{~min}$,

- viscosity of the liquid components of the abrasive slurry has no significant effect on the linear loss with a forced dosing system (in the tested range).

Presented solution of the dosing and application system of abrasive slurry allows to significantly reduce the costs associated with finishing machining and contributes to the development of automation of the lapping operations. The designed and made system enables the application of substances of various viscosities. Its advantage is also an even application of the abrasive slurry onto the working surface of the metal lapping disk, so that tool losses are as low as possible. 


\section{REFERENCES}

[1] Bakoń A., Barylski A. „Preparaty na bazie nano- i mikrodiamentów do operacji docierania i polerowania”. Mechanik. 87, 8-9 (2014): 8-12.

[2] Bakoń A., Barylski A. „Ziarna i mikroziarna diamentowe. Rodzaje ścierniw i przykłady zastosowania”. Gdańsk: Wydawnictwo Politechniki Gdańskiej, 2017.

[3] Barylski A. „Badania wpływu koncentracji ścierniwa i intensywności dawkowania zawiesiny na efekty docierania jednotarczowego". Mechanik. 88, 8-9 (2015): 20-24, http://dx.doi.org/10.17814/mechanik.2015.89.334 .

[4] Barylski A. „Docieranie powierzchni płaskich na docierarkach”. Gdańsk: Wydawnictwo Politechniki Gdańskiej, 2013.

[5] Barylski A. "Technological problems in lapping on flat surfaces of ceramic parts". Solid State Phenomena. 199 (2013): 627-632, https://doi.org/10.4028/www.scientific.net/SSP.199.627.

[6] Barylski A., Gniot M. "Wpływ zawiesiny ściernej dawkowanej w sposób wymuszony na wydajność docierania jednotarczowego elementów ceramicznych". Mechanik. 91, 8-9 (2018): 734-736, https://doi.org/10.17814/mechanik.2018.8-9.118.

[7] Box G., Hunter J. "Multifactor experimental designs for exploring response surfaces". Ann.Math.Statist. 28, 1 (1957).

[8] Gniot M., Barylski A., Migawa K. „System dawkowania zawiesiny ściernej w docieraniu powierzchni płaskich". Mechanik. 90, 10 (2017): 894-896, https://doi.org/10.17814/mechanik.2017.10.139.

[9] Gniot M., Barylski A. „Hydrodynamiczne dawkowanie zawiesiny ściernej w docieraniu jednotarczowym powierzchni płaskich". Mechanik. 89, 8-9 (2016): 1110-1111, http://dx.doi.org/10.17814/mechanik.2016.89.272 .

[10] Mańczak K. „Technika planowania eksperymentu”. Warszawa: WNT 1976.

[11] Marinescu I.D., Uhlmann E., Doi T.K. "Handbook of Lapping and Polishing. Manufacturing Engineering and Materials Processing". London, New York: CRC Press, Taylor \& Francis Group, 2007.

[12] Klocke F. "Manufacturing Processes 2 - Grinding, Honing, Lapping". Berlin-Heidelberg: Springer-Verlag, 2009.

[13] Polański Z. „Metody optymalizacji w technologii maszyn”. Warszawa: PWN, 1977. 